\title{
Vezetői státusz és kommunikáció a parancsuralmi rendszerben, különös tekintettel a Rendöri Hivatás Etikai Kódexére, valamint a vezetési stílusokra a Lasswell-modell alapján
}

\section{KOVÁCS István ${ }^{1}$}

\begin{abstract}
A személyes kapcsolatok a résztvevôk egymáshoz viszonyított hatalmi- és státuszhelyzete által meghatározottak. Különösen igaz ez a kommunikáció vonatkozásában is. A Rendőri Hivatás Etikai Kódexe szerint a vezetők személyes példamutatásukkal ösztönzik munkatársaikat, igénylik és meghallgatják véleményüket, tanácsaikkal, és iránymutatásukkal segítik a munkavégzést. A Lasswell által kidolgozott kommunikációs alapmodell azt vizsgálja, hogy a kommunikáció során ki, kinek és mit mond, milyen csatornán keresztül kommunikál, és mondandójával milyen hatást ér el. A tanulmány e modell alapján azt vizsgálja, hogy az autokrata, a demokratikus és a laissez-faire vezetési stílus kommunikációja a gyakorlatban hogyan valósul meg, érvényesülnek-e az etikai alapelvek.
\end{abstract}

Kulcsszavak: vezetési stílusok, vezetés- és szervezéselmélet, kommunikáció, rendőri etika, Lasswell-modell

\section{Bevezetés}

Néha a kimondott szavak sokkal nagyobb fájdalmat okoznak, mint azok a fizikális arculütések, amiket életünk során kaptunk, kapunk. Egy-egy jól irányzott, szóban vagy írásban megfogalmazott gondolat képes lehet arra, hogy a személyiségünkben mély nyomot hagyjon, romboló hatása nehezen gyógyuló sebként végigkísérheti életünket. Bár a véleménynyilvánítás, az emberi-, és alkotmányos szabadságjogok egyike, az korlátlanul mégsem gyakorolható. ${ }^{2}$

(Sokan az emberi jogokat meghallván a szólásszabadságra, a szabad véleménynyilvánításra vagy a vallás szabad megválasztására gondolnak, azonban ez meg sem közelíti a teljes és összes emberi jogot, amely létezik és megillet bennünket. Magyarország

KOVÁCS István, dr., PhD, r. őrnagy, tanársegéd. NKE RTK, Rendészeti Vezetéstudományi Tanszék István KOVÁCS, PhD, police major, assistant lecturer, NUPS Faculty of Law Enforcement https://orcid.org/00000002-7210-1981, kovacs.istvan@uni-nke.hu

2 Kovács István (2014) 419-430. 
Alaptörvénye Szabadság és felelösség fejezete kimondja, hogy az ember sérthetetlen és elidegeníthetetlen alapvető jogait tiszteletben kell tartani. Védelmük az állam elsőrendű kötelezettsége. Magyarország elismeri az ember alapvető egyéni és közösségi jogait. Alapvető jog más alapvető jog érvényesülése vagy valamely alkotmányos érték védelme érdekében, a feltétlenül szükséges mértékben, az elérni kívánt céllal arányosan, az alapvető jog lényeges tartalmának tiszteletben tartásával korlátozható.) ${ }^{3}$

Egy demokratikus társadalom múködése a jogok gyakorlásának, és a kötelmek végrehajtásának állami garanciáján nyugszik, amely minden demokráciát valló embertársunkra alkalmazható és alkalmazandó. Éppen ezért korántsem mindegy az, hogy véleményünket hogyan közöljük, ha azt nyilvánosságra hozzuk, akkor azzal embertársaink jogait és/vagy jogos érdekeit sértjük-e, veszélyeztetjük-e, avagy a joggyakorlás és kötelem teljesítése során tiszteletben tartjuk-e. ${ }^{4} \mathrm{~A}$ szakzsargon is így tartja: sokszor a fizikai sebek hamarabb gyógyulnak, mint a lelki sérülések. ${ }^{5}$ (Az orvostudomány álláspontja szerint ugyanis ilyen esetekben a krónikus stressz hatás megnövekszik, az immunsejtraktárak fokozatosan kiürülnek, csökken az immunválasz, ami elősegíti a betegségek kialakulását, és hátráltatja a gyógyulási folyamatokat.) ${ }^{6}$ Különösen igaz ez, emberi kapcsolatainkra, magánéletünkre, és munkahelyi viszonyainkra is egyaránt.

Ha önreflexiót gyakorlunk, biztos mindenkinek felelevenedik egy-egy olyan élmény, amikor főnökével összevitatkozott - bántó szavakat vágtak egymás fejéhez -, kollégáival nem voltak azonos állásponton - a kommunikáció az észérvek felsorakoztatásában nem segített -, vagy csupán nem lehetett a kommunikáció részese - mert feljebbvalója nem volt kíváncsi a véleményére. Bármennyire is igyekszünk a másikkal szemben toleránsnak lenni, alkalmazkodni, konszenzust kötni, nem tudunk mindenkinek megfelelni, de legyünk őszinték, nem is akarunk.

Ha a fentiek életünkben egyszer-egyszer előfordulnak, különösképpen nem is foglalkozunk velük, a gond akkor kezdődik, amikor az ilyen jellegű kommunikáció mindennapossá és természetessé válik. (Szerencsésnek érezhetjük magunkat, ha ilyen élményekkel eddig nem gazdagodtunk.) Ez a tanulmány egyrészt be szeretné mutatni, hogy milyen az, amikor valakinek vezetési stílusa és kommunikációja etikátlan magatartáson alapul, másrészt pedig ennek megfékezésére olyan javaslatokat kíván kidolgozni, amely a jövő vezetői kommunikációját nagymértékben segíti.

Kutatások bizonyítják, hogy azok az emberek, akik megértik, hogy a kommunikáció nem egyoldalú tevékenység, és nem csak arra használható, hogy annak segítségével mások személyiségét totálisan megsemmisítsék, emberi mivoltukban pedig e személyeket megalázzák, sokkal sikeresebb pályafutást tudnak maguk mögött, és sokkal inkább hozzájárulnak a szervezeti sikerekhez, mint társaik. ${ }^{7}$ Ugyanis a szavak nemcsak rombolni, hanem építeni is képesek, ami a motiváció egyik kulcseleme is egyben.

\footnotetext{
Kovács István (2016b) 109-126.

Kovács István (2017a) 449-484.

Martel (1998)

Péter (2008) 132-137.

Fairholm (2002)
} 
Akik az írásbeli, és szóbeli kommunikációs készségek széles körű, és legfőképpen etikus repertoárját alkalmazzák, már megtanulták, hogy az üzenetüket hogyan, mikor és legfőképpen milyen módon közvetítsék. Ez pedig kevésbé karakter, mint inkább kompetencia függvénye, tehát az egyén képességein alapul elsősorban. Akiknek viszont e készségeket elsajátítaniuk még nem sikerült, nemcsak önmagukra, hanem - a Lasswell-modell megállapításaival parallel módon - másokra is hatással lesznek, ami a vezetési stílusok függvényében, a munkavállaló munkához való hozzáállásában is tetten érhető, a korreláció mértéke pedig a szervezet teljesítmény-, eredményesség- és hatékonyságmutatóiban lesz mérhető.

Hiszek abban, hogy az ember tudatosan fejleszthető lény, aki élethosszig tanul, ha szükség van rá, önmagát akár autodidakta módon is képezi, hibáiból okul és minden körülmények között etikusan próbál cselekedni. Emberként meg kell próbálnunk nemcsak arra figyelni, hogy mit mondunk, hanem arra is, hogy az üzenetünket hogyan, kinek és milyen csatornán keresztül közvetítjük, mert könnyebb a prevenció eszközlésével a problémát megelőzni, mint a soha be nem hegesedő sebekre gyógyírt találni. Hiába ugyanis a mondás, miszerint a szó elszáll, ha az egyén már testi és lelki sérelmeket szenvedett.

Vajon a szigorúan centralizált rendőrségi modellben, amelynek működése a parancsra és a feltétlen engedelmességre épül - ahol a vezetési stílusok szinte mindegyike, vagy azok keresztmetszete megtalálható -, a vezetők részéről létezik-e olyan kommunikáció, amely az eredményességet fejleszti, az elvárt teljesítményt manifesztálja, és a hatékonyságot a munkavállalók munkavégzésének tükrében - annak hatására - produkálja, mindezt úgy, hogy a Rendőri Hivatás Etikai Kódexében foglalt ajánlásokat figyelembe veszi? Európában, ahol a határok egyre kisebb jelentőségűek, a rendőrségre irányuló figyelem magától értetődő. A viták középpontjában mindenekelőtt a rendőrség hatékonysága áll, az, miként képes felvenni a küzdelmet a bűnözéssel, és ezen belül a nemzetközi bűnözéssel, ám semmiképpen sem korlátozódik erre a kérdésre. A demokráciákban a rendőrség hatalmát keretek közé szorítja az, hogy mennyiben fogadható el az egyének alapvető jogai és szabadsága szempontjából. E két egyaránt fontos érdek között meg kell találni a helyes egyensúlyt, és rá kell lelni azokra az eszközökre is, amelyekkel az egyensúly fenntartható. A rendőretika esetében ez forog kockán. ${ }^{8}$ Van-e személyiségtorzítás, motiváló hatású-e a kommunikáció, vagy megtöri a tudatot, hogy a munkavégzés kérdés nélkül, futószalagszerűen realizálódjon? Vajon az autokrata vezető hajlamos arra, hogy uralja a beszélgetést, hangsúlyozza saját véleményét, és félbeszakítsa partnereit? Engedi-e a demokratikus vezető, hogy a kommunikáció során az állomány saját véleményét is ismertesse és akarata érvényesüljön? Egyenrangú-e a kommunikáció során a laissez-faire vezető a többi csoporttaggal szemben? Hipotézisem szerint vezetési stílustól függően alakul a kommunikáció, az üzenet (parancs, feladat, utasítás) hatást gyakorol a befogadóra, a kiváltott hatás pedig a vezetési stílus jellemzőivel korrelál.

\footnotetext{
Valcsicsák (2013)
} 
Mindennek tesztelésére az adatgyưjtő tevékenység mellett - primer és szekunder források felhasználása - forráskritikát alkalmaztam. Az elméleti szakasz absztraktálható, logikai erőfelhasználást követelt meg, az analízis és szintézis dialektikus felhasználása segített abban, hogy a vizsgált témakört (lényeges tulajdonságainak, strukturális elemeinek és egyes kapcsolatainak szétválasztásával) gondolati részekre bonthassam, majd minden egyes részt - felépítés és funkcionalitás szerint - az egészhez való viszonyulása alapján feltérképezzem.

Általános stratégiai célomnak tekintettem, hogy vezetés- és szervezéselmélet tárgykörben olyan innovatív fejlesztési javaslatokat fogalmazzak meg, amely a leendő pályakezdő rendőri vezetők gyakorlati, szerven belüli, illetve legfőképpen etikus kommunikációját és annak alkalmazását segíti.

\section{Kommunikáció és a Lasswell-modell}

Kommunikációnk során érzéseink, kívánságaink, személyiségünk jellemző attitűdjei megjelennek. Ez az interakció - egész életünkben - végigkísér bennünket, ahogy fejlődünk, ahogy személyiségünk változik, úgy változnak a diskurzus elemei is egyben. Ez hálózza be életünket, ez jelenik meg emberi kapcsolatainkban is. Ezek a kapcsolatok nemcsak magánéletünkben, hanem munkahelyünkön, munkahelyi viszonyainkban is mint annak kritikus elemei vannak jelen. Kritikus, hiszen a klasszikus kommunikációs folyamat különböző elemei - feladó, vevő, üzenet, csatorna, zaj, visszacsatolás és a „beállítás” - nem mindegy, hogy milyen kontextusban, milyen módon, hol és miért jelenik meg. ${ }^{9}$ Gondoljunk csak bele: ez az egyszerű, de mégis komplex folyamat, amelyben az emberek információkat, ötleteket, érzéseket osztanak meg egymással, vagy környezetükkel mennyi féle és fajta lehet. A bevezetésben tárgyalt szavak súlya, az írásos anyagok jelentősége, vagy a nem verbális jelek - arckifejezés, gesztus, testtartás - és a tiszta csend is eszköze lehet ennek a kritikus struktúrának, ami befolyással bír majd embertársaink vonatkozásában. Ezért sem mindegy, hogy hogyan kommunikálunk, milyen jeleket küldünk, és az a vevőnél milyen hatást ér el, a visszacsatolás milyen jellegű lesz. A Lasswell féle modell középpontjában is ezen elemek vizsgálata áll.

A kommunikációelmélet számos tudományág, és tudományterület eredményeit ötvözi. A műszaki tudományok nagymértékben befolyásolták, és segítették a kommunikációelmélet kialakulását, de önmagában a legalkalmasabbnak a kommunikációs folyamatok vizsgálatára a kétszemélyes, közvetlen kommunikáció bizonyult, hiszen a kommunikációban a biológiailag, pszichológiailag és szociálisan meghatározott ember vesz részt.

Lasswell, behaviorista kutatóként ezt mindvégig szem előtt tartotta: egy olyan alapmodellt hozott létre, amelynek során azt vizsgálta, hogy ki, kinek és mit mond, azt milyen csatornán keresztül teszi, és a mondandójával milyen hatást ér el. Ez már az interperszonális (azaz a személyközi) kommunikációs helyzetnél tágabban volt értelmezhető,

\footnotetext{
Gordon (1977)
} 
hiszen a kommunikációt nemcsak materiálisan, hanem pszichológiai vonatkozásaiban is elemezte, sőt már a propaganda jelenségek értelmezése is foglalkoztatta. A Lasswelltézis szerint: a kommunikációkutatásban azt kell vizsgálni, hogy ki, mit mond, milyen kommunikációs csatornán keresztül, kinek és milyen eredménnyel teszi. ${ }^{10}$ Ezt az alábbi folyamatábrán illusztrálom:

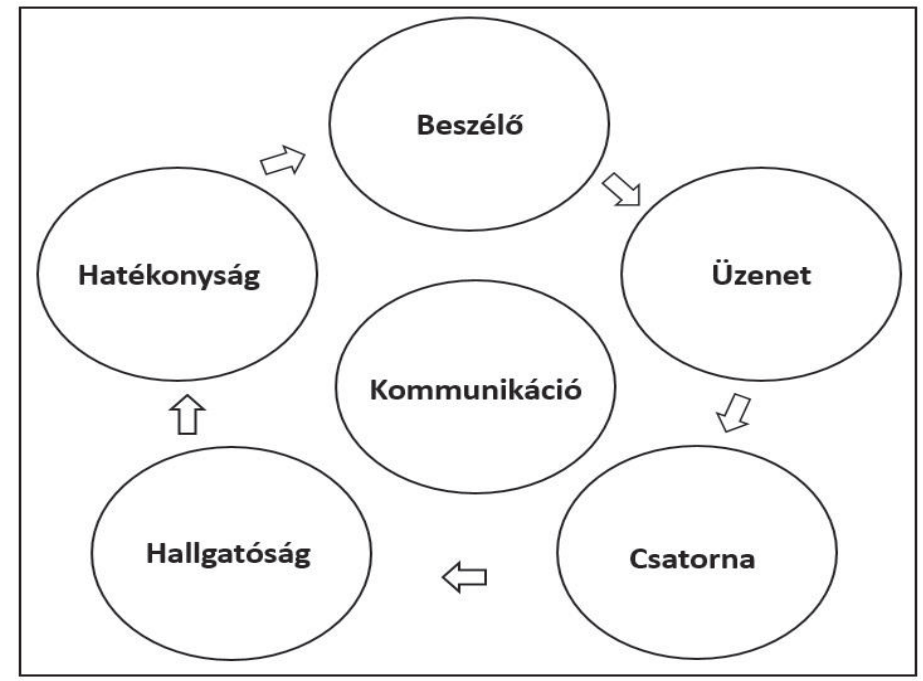

1. ábra: A Lasswell-féle kommunikációs modell. Forrás: szerkesztette a szerző

A modellben első helyen a közlő (beszélő), azaz a „ki” elem áll. Beszélő az a személy, akitől adott helyzetben a kommunikáció elindul. Második a „mit”, vagyis az üzenet. A közlés tartalma, értelme mindig a hír, közléstartalom, vagyis önmagában az üzenet. A kör harmadik állomása a csatorna. A csatorna segít abban, hogy az üzenet - a térben és időben elkülönülő adatok, jelek, információk - átvitele megvalósuljon. A periódus negyedik eleme a „kinek”, azaz a hallgatóság köre. Hallgatónak tekintünk mindenkit, aki a közlést kapja, felfogja, azaz befogadóvá válik. A fázis utolsó helyén a hatékonyság szerepel, amit az üzenet eredményével azonosíthatunk. Hatékonyság, vagyis annak megnyilvánulása, hogy az adott üzenet a kívánt hatást elérte-e.

A modellt korábban olyan szempontú kritika érte, miszerint a folyamatból a „miért” kérdésre adott válasz hiányzott. A kommunikáció folyamatában már pedig a „miért” kérdésre adott válaszoknak jelentőségük van, hisz önmagát a kommunikációs cselekvést, vagy cselekvéssort olyan indíték hozza mozgásba, amely a miértekre adott válaszokkal megegyezik. A folyamat végén így jön létre a „kapcsolat”, ami az egyén, és társadalmi létszükséglet formájában realizálódik. A társadalom nem képzelhető el tudatos, ter-

10 Lasswell (1948) 
vezett, szervezett és leginkább célirányos kapcsolati háló nélkül. Ez egy olyan alaptézis, ami a miértekre támaszkodik. Minél mélyebb a miértek vizsgálata, annál inkább valószínúbb, hogy a mögötte húzódó érdek, vagy indok tökéletesebben tud beilleszkedni abba a társadalmi kapcsolatrendszerbe, ahová tartozik. Ezért szükséges, hogy ezt az elemet az állapotsorba beemeljük. A miért napjainkban bármi lehet - például termék, személy, szolgáltatás -, de a tanulmány szempontjából a társadalmi igény kielégítése, azaz a belső rend, a közbiztonság megteremtése jut szerepkörhöz.

Ha a modellt a rendőrség vonatkozásában, a parancsuralmi rendszerben helyezzük el, a közlőt a parancsnokkal (felső, közép- vagy alsó vezető), az üzenetet a paranccsal (utasítás, iránymutatás, intézkedés), a csatornát a fórummal, a hallgatóságot a végrehajtói állománnyal, a hatékonyságot az eredményességgel és a feladatvégrehajtással azonosíthatjuk. (A kommunikációs csatorna szempontjából érdekesség, hogy például 1963-ban a Belügyi Szemle fórumul szolgált a hazai és külföldi elméleti, gyakorlati problémák, tapasztalatok megismertetéséhez, megvitatásához, elemzéséhez, értékeléséhez, miközben erősítette a hazai belügyi szervek együttmúködését, munkakapcsolatait.) ${ }^{11}$ A miért kérdésre pedig a közbiztonság megteremtése, azaz az egyik legösszetettebb társadalmi igény kielégítése adható mint válasz. Ezt az alábbi folyamatábrán szemléltetem:

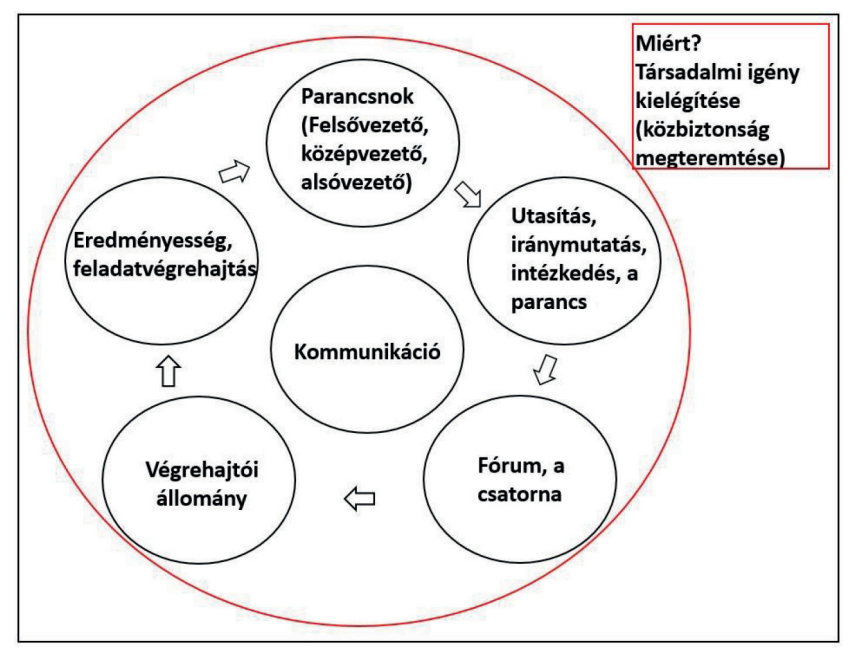

2. ábra: A Lasswell-féle kommunikációs modell a rendörség vonatkozásában.

Forrás: szerkesztette a szerző

Egy korábban készült tanulmány szerint a szituációs vezetés sikeres használata négy kommunikációs komponens hatékonyságára támaszkodik: az elvárások kommuniká-

11 Deák (2014) 136.; Deák (2016) 47. 
lása, a hallgatás, a delegálás és a visszajelzés biztosítása. ${ }^{12} \mathrm{E}$ tanulmány keretén belül viszont szeretném megvizsgálni, hogy vajon a vezetési stílusok tényleg milyen mértékben, és hogyan alkalmazzák a Lasswell-modell elemeit, legfőképpen a társadalmi cél és a munkavállaló eredményorientáltsága azzal milyen mértékben, egyáltalán korrelál-e.

\section{Rendőrségi hierarchia: etika és a vezetési stílusok}

Alapvető társadalmi igény, hogy az állami szervek munkatársai feladataikat kötelességtudóan, szakszerűen, felelősséggel végezzék. A hivatásos, és közszolgálati dolgozók munkavégzését, mindennapjait az adott területre vonatkozó jogszabályi rendelkezések a pártatlan, előítéletektől és befolyástól mentes feladatellátás elvárásaival kiegészítve határozzák meg. ${ }^{13}$ A dualizmuskori „haza és haladás” mottóját, a 21. században a rendvédelmi szervek körében a „személy, biztonság, és integritás” szolgáltatása egészítette ki. A politikai elvárások, a gazdasági körülmények, de leginkább a társadalom tagjainak szubjektív biztonságérzete a rendvédelmi szerveket tevékenységük minőségének fejlesztésére késztetik. A követelményeknek való megfelelést a társadalom tagjainak értékítélete mellett, döntő mértékben a rendészet kultúrája, és a rendvédelmi szervek értéke határozza meg. Ahhoz, hogy a rendvédelmi szervek társadalmi rendeltetésüknek megfelelni tudjanak, mindezek mellett szükségük van arra is, hogy az állampolgárok támogatását megkapják. A megbecsülés, és támogatás mércéjét ugyanis mindig az állampolgárok alakítják. ${ }^{14} \mathrm{Ha}$ az állampolgár elégedett, vélhető, hogy a társadalmi rendeltetés, a kormány által kitűzött cél révbe ért.

A kiadott feladatok viszont csak úgy érvényesíthetők, ha a rendőrök a napi feladataikat szigorúan a jogszabályok betartásával hajtják végre. Amennyiben az állampolgároktól elvárjuk, hogy normaszerűen éljék életüket, akkor a szabályokat a rendőrségnek nemcsak betartatnia, hanem betartania is szükséges.

\section{A parancs szerepe}

A rendőrség irányításában speciális szabályzók érvényesülnek. A specialitással összefüggésben két alapelvről (egyszemélyi vezetés és a centrális vezetés elve) is szólnunk szükséges. Az egyszemélyi vezetés elve értelmében a szervezet vezetője a szervezet jogszerű múködéséért, illetve tevékenységéért teljes és oszthatatlan felelősséggel tartozik. ${ }^{15}$ Normaszerû múködés, normaszerű feladatvégzés. Ezt biztosítja a centrális vezetés elve. A centrális vezetés elve alapján a szervezet elsődleges vezetőjétől kapott parancsokat a szervezetben vezetői tisztséget betöltő személyek (is) kötelesek végrehajtani és azt

\footnotetext{
Covey (1991)

Kovács István (2015a) 42-60.

Kovács István (2015b) 99-125.

Miller (2014) 1-8.; Fogarasi-Kovács (2016) 19-41.
} 
az állománnyal végrehajtatni. ${ }^{16}$ (Ez kiegészül azzal, hogy a vezetőknek ellenőriznie is kell a szakszerű és jogszerű végrehajtást. ${ }^{17} \mathrm{Az}$ egymás közötti kapcsolatot a szolgálati úton megvalósuló parancsirányítási rendszer útján gyakorolják, amelyhez a vezetők sajátos, a parancsnoki jogkört birtokolnak. (A parancs a katonai szolgálati rend és fegyelem biztosításának legelemibb része. $)^{18}$ A rendészeti szervezetben a vezetôt és beosztottat egyaránt írott jogszabályok kötik, amelyek a vezető munkakapcsolatait szabályozzák. Ez legegyszerúbben a vezető utasítási (parancsadási) jogával és a beosztott végrehajtási kötelezettségével jellemezhető. ${ }^{19}$ Nagyon fontos viszont kiemelni, hogy a parancsuralmi rendszer egy olyan visszacsatoláson múködő zárt architektúrát alkot, amely a parancsnok tekintélyének biztosítása mellett, a parancs végrehajtójának személyét (a támadásoktól) megvédi, és az állampolgárok biztonság iránti igényét kielégíti. Mindez azt szolgálja, hogy a kiadott utasítás alapján a személyek felelőssége egyértelműen meghatározhatóvá váljék, és a szerv működésébe vetett társadalmi bizalom ne sérülhessen.

Ennek illusztrációs, majd szöveges magyarázatát az alábbi ábrán tekinthetjük meg.

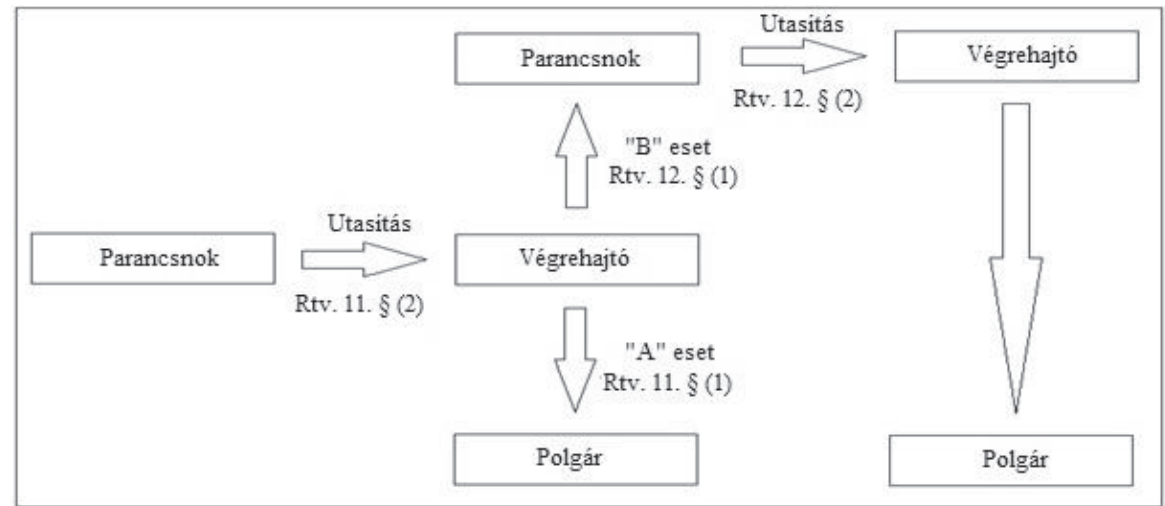

3. ábra: A parancsuralmi és egyéni felelösség rendszere. Forrás: szerkesztette a szerző

A parancsnok feladatot határoz meg, azt parancs formájában a végrehajtó irányába továbbítja. A parancs végrehajtója a szolgálati beosztásában meghatározott feladatait a törvényben foglaltaknak megfelelően végrehajtani, valamint az elöljáró által adott utasításoknak engedelmeskedni köteles. ${ }^{20}$ A rendőrség jog- és szakszerű feladatellátásának alapfeltétele, hogy annak tagjai minden esetben egységesen értelmezzék

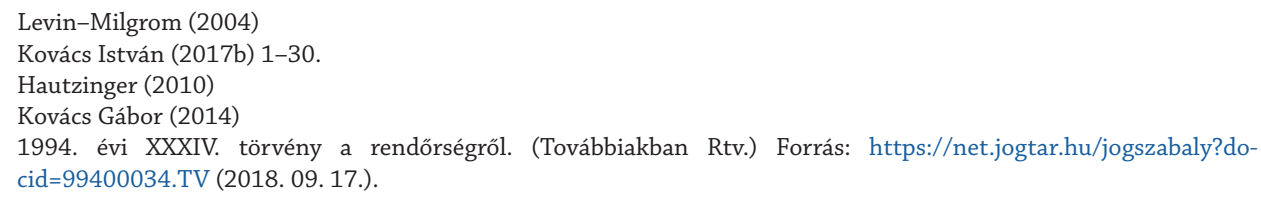


és hajtsák végre a testület számára meghatározott szabály- és elvárási rendszerekben megfogalmazott utasításokat, parancsokat. Az utasítás végrehajtása két esetet feltételez.

„A” esetben az utasítás kiadása jogszerű és szakszerû volt, a végrehajtó azt a rendőrségi törvényben meghatározott módon köteles végrehajtani, a polgárnak pedig alá kell vetnie magát az intézkedésnek magát. „A” esetben nem volt törvénysértő aktus, a jogszerűségért és a szakszerűségért mind a parancsnok, mind a végrehajtó, valamint akár a polgár felelőssége egyértelműen meghatározható. ${ }^{21}$

„B” esetben viszont az utasítás kiadása törvénysértő. Büncselekmény esetén azt a végrehajtó köteles megtagadni, szabálysértés esetén pedig fel kell hívnia a parancsnok figyelmét annak jogszabálysértő voltára. Ilyenkor a parancs végrehajtásának nincs halasztó hatálya, azonban ha mindezek ellenére az elöljáró fenntartja a parancs kiadását, köteles azt az utasított kérelmére írásba foglalni. A fenti esetben a jogszerűség és szakszerűség kérdésköre, az egyéni felelősség megállapítása szintén egyértelműsíthető. ${ }^{22}$ (Itt kívánom megjegyezni, hogy a végrehajtó felelőssége az esetben is megállapítható, ha az időközben felmerülő információkról, a bekövetkező eseményekről és a változásokról az elöljárót nem értesíti, ad absurdum a vezetői döntést befolyásolják.)

Egy olyan szerv, mint a rendőrség nem múködhet szigorú jogszabálybetartás és végrehajtás nélkül. A parancs iránti feltétlen engedelmesség és egyéni felelősségmegállapító rendszer biztosítja, hogy a vezetés- és irányításmátrix működőképes, az állami cél elérhető, és végül az állampolgárok biztonság iránti igénye kielégítést nyerjen. Nem mindegy azonban, hogy ebben a rendszerben az utasítást adó jogkörrel rendelkező parancsnok milyen vezetési stílust alkalmaz. A szakirodalom három vezetési stílust ismertet, amely az alábbiakban érhető tetten.

\section{Vezetési stílusok}

Az autokratikus vezetési módszer a félelem és a nyomás megtestesítője. Fenyegetésekre, büntetésre támaszkodik, amely a munkavállalót befolyásolja. A szervezetbe újonnan bekerülő személyek vonatkozásában használják a leggyakrabban, akik nem tudják még, hogy milyen feladatokat kell elvégezniük vagy milyen eljárásokat kell követniük. A vezető hatékony felügyelettel, a feladatok részleteinek meghatározásával, és azok végrehajtásának visszaellenőrzésével vezeti a szervezeti egységet. A döntést kizárólag a vezető hozhatja meg. ${ }^{23}$ A rendőri feladatvégzés tekintetében a parancsnoki kontroll jelenléte maximális, ami manuális szakvezetéssel párosul. Az aktuális végrehajtói szint alapfeladatát szigorú kontroll, beszámoltatás jellemzi. A munkafeladatok tekintetében az adott szint a végrehajtói hierarchia legalacsonyabb szintjén helyezkedik el, amely mindennapos, részfeladatonkénti beszámoltatást, végrehajtási ellenőrzést, utasításkiadást feltételez. A vezető a döntéseket, részfeladatonként és összességében is kizárólagosan csak maga hozhatja meg.

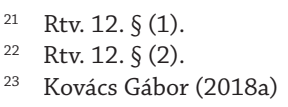


A demokrata vezetési stílus a vezető és a végrehajtó közötti korszerű együttmúködés jelképe. Bár a végső döntést a vezető hozza meg, a végrehajtót annak folyamatába bevonja - döntési alternatívákat vázol - a személyek a döntési mechanizmus szerves részét képezik. Ez az elégedettséget növelése mellett az emberek saját kompetenciáinak fejlesztését szolgálja, azáltal, hogy a végrehajtók hasznosnak érzik magukat, motiváltakká válnak. ${ }^{24} \mathrm{E}$ tekintetben a parancsnoki kontroll jelenléte minimális, ami részellenőrzésekkel párosul. Az aktuális végrehajtói szint feladatát folyamatos belső és külső együttmüködéssel hajtja végre. A munkafeladatok tekintetében az adott szint a végrehajtói hierarchia olyan szintjén helyezkedik el, amely lehetőséget teremt arra, hogy részvezetői feladatokkal, azaz szolgálati csoportvezetői feladatokkal is megbízhatóvá válik. A vezető döntési alternatívákat kínál, amelyek közül a legoptimálisabbat együtt, megbeszélés útján választják ki.

A laissez-faire vezetési stílus úgy foglalható össze, mint a „vezetés hiánya”, vagy a „leveszem a kezem rólatok" megközelítés. ${ }^{25} \mathrm{~A}$ vezető az aktív részvételt a célok meghatározásában, az elvárások tisztázásában, a prioritások szervezésében és az érintettek bevonásában elkerüli. A vezető rendkívül passzív és inaktív is egyben, amely azt eredményezi, hogy a vezetett személy önigazgatóvá válik. ${ }^{26} \mathrm{E}$ tekintetben a parancsnoki kontroll jelenléte kizárólag szükség esetén valósul meg, annak minősége elhanyagolható. Az aktuális végrehajtói szint feladatát önállóan hajtja végre, anyagait önállóan készíti el. A munkafeladatok tekintetében az adott szint a végrehajtói hierarchia olyan magas fokán helyezkedik el, hogy - önálló vezetési jogkör gyakorlásának delegálásával - szolgálati feladat ellátása érdekében létrehozott munkacsoport vezetésével is megbízható. A tevékenysége során hozott döntéseket önállóan is meghozhatja, vezetői kontroll nélkül.

\section{Etika}

A társadalom által támasztott követelményeknek való megfelelést döntő mértékben a rendészet kultúrája és a rendőri szervek értéke határozza meg. A szervezeti kultúra megtartására és fejlesztésére az erkölcs, az etika és az etikai kódex is segítségül van. Kutatások igazolják, hogy lényeges szempont, hogy a rendőri hivatásból eredő és azzal öszszefüggésben felmerülő etikai, erkölcsi problémákat az egyén vonatkozásában a lehető leggyorsabban és a leghatékonyabban szükséges vizsgálni és kezelni. ${ }^{27}$ Ennek érdekében dolgozták ki modell szintjén a rendőrség pszichológiai szolgálata mellett a katolikus rendőrségi lelkipásztori szolgálatot mint a hivatásból eredő etikai és erkölcsi problémák kezelésére megoldást nyújtó szervezeti struktúra modelljét. ${ }^{28}$

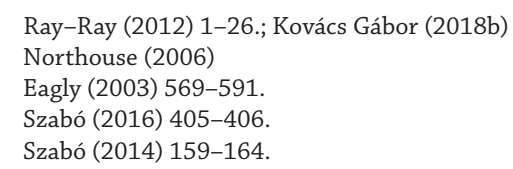


A témával összefüggésben a parancsnokokra irányuló kötelmek a kódexben három pontban jelennek meg: a bajtársiasságról, a felelősségről és a vezetőkről szóló témakörökben. A bajtársias rendőr(parancsnok) együttműködik munkatársaival, velük kulturáltan, a kölcsönös tisztelet és megbecsülés szellemében érintkezik. (Az a fajta megnyilvánulás, és kommunikáció, ami lealacsonyító értékítéletet közvetít, tiszteletlen és megalázó a rendőri hatalmi visszaélések csoportjába tartozik. Használata tiltott. ${ }^{29}$ Önzetlen támogatást nyújt, a problémák megoldását elősegítő légkör kialakítására törekszik. Felelős vezető a parancsnok, ha döntési, cselekvési kötelezettségét mindenkor késedelem nélkül, aktívan vállalja, a felelősséget másra alaptalanul nem hárítja át. Hibás döntései következményeit lehetőségei szerint orvosolja. Tudatában van annak, hogy saját személyén keresztül az egész testület megítéléséért is felelős. A vezetőnek mindig tiszteletben kell tartania a beosztottak emberi méltóságát, gondoskodnia kell róluk, megbecsüléssel, és részrehajlás nélkül kell őket irányítania. Személyes példamutatásával ösztönöznie kell munkatársait, véleményüket meg kell hallgatnia - erre igénynek is mutatkozni kell - a munkavégzést tanácsaival és iránymutatásával támogatnia kell.

Most, hogy képet kaptunk a vezetési stílusokról, és arról, hogy milyen követelményeket támaszt a Rendőri Hivatás Etikai Kódexe a felelős vezetővel szemben, ideje elemeznünk, hogy a különböző vezetési stílusokhoz milyen kommunikáció társul, az a végrehajtói állomány munkavégzésére milyen hatást gyakorol, vajon az autokrata, a demokratikus vagy a laissez-faire diskurzusa felel meg leginkább a moralitás törvényeinek. (Megjegyzés csupán, de érdemes elgondolkodnunk rajta, hogy az ember személyisége felerősíti az alkalmazott vezetői stílus tulajdonságait. A jellem egyik legáltalánosabb kísértéseként a hatalom befolyásoltságát tartják számon. A hatalom és az erkölcs mint a kísértésekre adott válaszreakció szoros összefüggésben áll egymással. ${ }^{30}$ )

\section{Vezetési stílusok és kommunikáció}

Minden szervezet, így a rendészeti szervezetek müködésének alapja is a hatékony kommunikáció. ${ }^{31} \mathrm{Az}$ eredményes kommunikáció képessége a müködés sikerességét biztosítja. A kommunikáció minden vezetési szintnél és formánál egyaránt jelentős szerepet játszik. E vezetési folyamatban valósul meg az a vezetői funkció, amelynek során a vezető vezeti munkatársai (beosztottjai) tevékenységét és irányítja az alárendelt szervezetek munkáját. ${ }^{32}$ Ezért van kiemelt jelentősége annak, hogy a vezető milyen kommunikációs közeget, illetve ő maga milyen kommunikációt használ.

A tanulmány a vezetői kommunikáció folyamatát két különböző diskurzustípuson keresztül vizsgálta. Kommunikáció interperszonális és kiscsoportos környezetben.

\footnotetext{
29 Kovács István (2016a)

30 Ranschburg (2013)

31 Kovács Gábor (2018)

32 Kovács Gábor (2016) 381-394.
} 
Interperszonális a kommunikáció, amikor szemtől szemben, egy az egy alapon folytatunk beszélgetést, és mindezt informális környezetben tesszük. ${ }^{33} \mathrm{Ez}$ a fajta kommunikáció kínálja a legnagyobb lehetőséget arra, hogy a résztvevők közötti diskurzusok produktív kimenetelüvé váljanak, mind a feladónak, mind a vevőnek nagy esélye van arra, hogy az üzenetet a csatornákon keresztül megfelelő módon megkapja és megértse. ${ }^{34}$ Kiscsoportos a kommunikáció, amikor a probléma megvitatásában vagy megoldásában több ember vesz részt. Erre tekintettel a kommunikáció akár zavart is okozhat, mivel több küldő és fogadó is van a beszélgetésben. ${ }^{35}$

A vezetési stílusokat e két kategória értelmezésével parallel elemeztem, meghatározva különböző tulajdonságaikat.

$\mathrm{Az}$ interperszonális környezetben gyakorolt vezetési stílusok kommunikációjának elemeit az alábbi táblázatba rendeztem:

1. táblázat: Az interperszonális kommunikáció a vezetési stílusok jegyében. Forrás: szerkesztette a szerzö

\begin{tabular}{|c|c|c|c|c|c|}
\hline & $\begin{array}{l}\text { Kommunikáció } \\
\text { kezdemé } \\
\text { nyezése }\end{array}$ & $\begin{array}{c}\text { Alárendeltek } \\
\text { érdekeinek } \\
\text { figyelembe- } \\
\text { vétele }\end{array}$ & $\begin{array}{c}\text { Kommunikáció } \\
\text { iránya }\end{array}$ & $\begin{array}{c}\text { Visszacsa- } \\
\text { tolás }\end{array}$ & Hatékonyság \\
\hline \multicolumn{6}{|c|}{ Interperszonális } \\
\hline Autoriter & $\begin{array}{l}\text { A kommunikáció } \\
\text { kezdeménye- } \\
\text { zője kizárólag, } \\
\text { és egyszemélyben } \\
\text { a vezető, } \\
\text { a végrehajtónak } \\
\text { nincs kezdemé- } \\
\text { nyezési jogköre. }\end{array}$ & $\begin{array}{l}\text { A vezető szemtől } \\
\text { szemben is saját } \\
\text { érdekeit veszi } \\
\text { csak figyelembe, } \\
\text { annak pontosan } \\
\text { meg kell felelni. } \\
\text { A végrehajtónak } \\
\text { nincs érdekérvé- } \\
\text { nyesítési lehető- } \\
\text { sége. }\end{array}$ & $\begin{array}{l}\text { Vezetőtől } \\
\text { a végrehajtó } \\
\text { felé, } \\
\text { egyoldalúan. }\end{array}$ & $\begin{array}{l}\text { A végrehajtó } \\
\text { részéről nincs } \\
\text { lehetőség } \\
\text { a visszacsato- } \\
\text { lásra, mondan- } \\
\text { dójában félbe- } \\
\text { szakítják. }\end{array}$ & $\begin{array}{l}\text { Hatékonysága } \\
\text { gyenge, mert } \\
\text { egyoldalú állás- } \\
\text { pontra rendez- } \\
\text { kedik be, a másik } \\
\text { fél véleményére } \\
\text { nem kíváncsi. } \\
\text { A kommunikáció } \\
\text { egyoldalúsága } \\
\text { sikertelenséghez } \\
\text { vezethet. }\end{array}$ \\
\hline Demokratikus & $\begin{array}{l}\text { A kommunikációt } \\
\text { kezdeményezhe- } \\
\text { ti a végrehajtó, } \\
\text { és a vezető egy- } \\
\text { aránt. Az aláren- } \\
\text { delt felhatalma- } \\
\text { záshoz jut. }\end{array}$ & $\begin{array}{l}\text { A kommunikáció } \\
\text { során az aláren- } \\
\text { deltek érdekét is } \\
\text { képviselik, azt } \\
\text { a vezető meghall- } \\
\text { gatja, figyelembe } \\
\text { veszi. }\end{array}$ & $\begin{array}{l}\text { A kommuni- } \\
\text { káció iránya } \\
\text { kétoldalú, } \\
\text { vezetőtől, } \\
\text { és végrehajtó- } \\
\text { tól is folyama- } \\
\text { tos. }\end{array}$ & $\begin{array}{l}\text { A végrehajtó } \\
\text { felhatalma- } \\
\text { zást kap, hogy } \\
\text { az elhangzot- } \\
\text { takra reagál- } \\
\text { jon, és reflek- } \\
\text { táljon. }\end{array}$ & $\begin{array}{l}\text { A hatékonyság } \\
\text { erős, mert mind- } \\
\text { két fél véleménye } \\
\text { megismerhetővé } \\
\text { válik, } \\
\text { és konszenzus } \\
\text { kialakítására } \\
\text { törekszik, ami } \\
\text { a siker kulcsaként } \\
\text { értelmezhető. }\end{array}$ \\
\hline
\end{tabular}




\begin{tabular}{|c|c|c|c|c|c|}
\hline & $\begin{array}{l}\text { Kommunikáció } \\
\text { kezdemé } \\
\text { nyezése }\end{array}$ & $\begin{array}{l}\text { Alárendeltek } \\
\text { érdekeinek } \\
\text { figyelembe- } \\
\text { vétele }\end{array}$ & $\begin{array}{c}\text { Kommunikáció } \\
\text { iránya }\end{array}$ & $\begin{array}{l}\text { Visszacsa- } \\
\text { tolás }\end{array}$ & Hatékonyság \\
\hline Laissez-faire & $\begin{array}{l}\text { Kommunikáci- } \\
\text { ót a végrehajtó, } \\
\text { és a vezető is } \\
\text { kezdeményezhet, } \\
\text { de általában a ve- } \\
\text { zetőtől indul. }\end{array}$ & $\begin{array}{l}\text { Az alárendelt } \\
\text { érdekét a vezető } \\
\text { figyelembe veszi, } \\
\text { mert a feladat- } \\
\text { végrehajtás során } \\
\text { módszert nem } \\
\text { határoz meg. } \\
\text { Szabadelvűségre } \\
\text { alapoz. }\end{array}$ & $\begin{array}{l}\text { A kommuni- } \\
\text { káció iránya } \\
\text { kétoldalú, ve- } \\
\text { zetőtől és vég- } \\
\text { rehajtótól is } \\
\text { folyamatos. } \\
\text { Annak mód- } \\
\text { szere viszont } \\
\text { relatív önálló- } \\
\text { ságot mutat. }\end{array}$ & $\begin{array}{l}\text { A végrehajtó } \\
\text { felhatalma- } \\
\text { zást kap, hogy } \\
\text { az elhangzot- } \\
\text { takra reagáljon } \\
\text { és reflektáljon, } \\
\text { de a vezető } \\
\text { részéről a kö- } \\
\text { zömbösség } \\
\text { itt is tetten } \\
\text { érhető. }\end{array}$ & $\begin{array}{l}\text { Hatékonysága } \\
\text { közepes, mert } \\
\text { bár keretet szab, } \\
\text { és a végrehajtó } \\
\text { kreativitását erő- } \\
\text { síti, mégsem kon- } \\
\text { szenzusra, hanem } \\
\text { közömbösségre, } \\
\text { és magától mükö- } \\
\text { dő/müködtethető } \\
\text { folyamatokra } \\
\text { épít. }\end{array}$ \\
\hline
\end{tabular}

Az interperszonális kommunikáció során az autoriter vezetési stílus esetében a kommunikációt a vezető kezdeményezi, a végrehajtói állomány nem kezdeményezhet beszélgetést. A vezető kizárólag a saját érdekeit tartja szem előtt, amelynek pontosan meg kell felelni. A végrehajtónak nincs érdekérvényesítési lehetősége. A kommunikáció a vezetőtől a végrehajtó felé irányul, az egyoldalú és lineáris. A végrehajtó nem reagálhat a vezető által elmondottakra, nem kap rá lehetőséget, hogy az elhangzottakra kritikai észrevételeket tegyen. Hatékonysága e környezetben gyenge, mert egyoldalú álláspontra rendezkedik be, a másik fél véleményének megismerésére nem mutat affinitást. A kommunikáció egyoldalúsága sikertelenséghez vezethet.

Demokratikus vezetési stílust gyakorlók vonatkozásában nemcsak a vezető, hanem a végrehajtó is kezdeményezhet kommunikációt. Ez a végrehajtói oldalon az alapfeladatok ellátásán túl többletjogosultságokat feltételez, amelyet a kommunikáció kétoldalú és folyamatos iránya és jellege biztosít. Visszacsatolás tekintetében a végrehajtó felhatalmazást kap, hogy az elhangzottakra reagáljon és reflektáljon. A hatékonyság erős, mert mindkét fél véleménye megismerhetővé válik, kompromisszum révén pedig a siker biztosítható.

A laissez-faire stílus biztosítja, hogy a kommunikációt mindkét fél kezdeményezhesse, de annak általános jellegéből adódóan az a vezetőtől indul. A vezető nem határoz meg módszert a tekintetben, hogy a feladatvégrehajtás hogyan történik, ezzel bizonyítva az alárendelt érdekeinek képviseletét. Szabadelvűségre alapoz. A kommunikáció iránya kétoldalú, vezetőtől és végrehajtótól is folyamatos. Annak módszere viszont relatív önállóságot mutat. Ugyan a végrehajtó az elhangzottakra reflektálhat, de a vezető szabadelvűségére tekintettel abban a közöny tetten érhető. Hatékonysága közepes, mert bár keretet szab, és a végrehajtó kreativitását erősíti, mégsem konszenzusra, hanem közömbösségre, és magától működő/működtethető folyamatokra épít.

A kiscsoportos környezetben gyakorolt vezetési stílusok kommunikációjának elemeit az alábbi táblázatba rendeztem: 
2. táblázat: A kiscsoportos kommunikáció a vezetési stílusok jegyében. Forrás: szerkesztette a szerző

\begin{tabular}{|c|c|c|c|c|c|}
\hline & $\begin{array}{l}\text { Kommuniká- } \\
\text { ció kezdemé- } \\
\text { nyezése }\end{array}$ & $\begin{array}{c}\text { Alárendeltek } \\
\text { érdekeinek } \\
\text { figyelembevétele }\end{array}$ & $\begin{array}{l}\text { Kommuni- } \\
\text { káció iránya }\end{array}$ & $\begin{array}{c}\text { Visszacsa- } \\
\text { tolás }\end{array}$ & Hatékonyság \\
\hline \multicolumn{6}{|c|}{ Kiscsoportos } \\
\hline Autoriter & $\begin{array}{l}\text { A kommuni- } \\
\text { káció kezde- } \\
\text { ményezője } \\
\text { kizárólag, } \\
\text { és egyszemély- } \\
\text { ben a vezető, } \\
\text { a végrehajtók- } \\
\text { nak nincs kez- } \\
\text { deményezési } \\
\text { jogköre. }\end{array}$ & $\begin{array}{l}\text { A csoport érdekei- } \\
\text { nek figyelembevétele } \\
\text { elmarad, a vezető } \\
\text { csak a saját érdekeit } \\
\text { kommunikálja, és va- } \\
\text { lósítja meg. }\end{array}$ & $\begin{array}{l}\text { A kommuni- } \\
\text { káció egyirá- } \\
\text { nyú, a csopor- } \\
\text { ton belül csak } \\
\text { a vezetőtől } \\
\text { indul, és nála } \\
\text { is fejeződik } \\
\text { be. }\end{array}$ & $\begin{array}{l}\text { Visszacsa- } \\
\text { tolás a cso- } \\
\text { port tagjai } \\
\text { részéről nem } \\
\text { lehetséges, } \\
\text { a vezető } \\
\text { egyoldalúan } \\
\text { kommunikál. }\end{array}$ & $\begin{array}{l}\text { Hatékonyság te- } \\
\text { kintetében gyen- } \\
\text { ge, tekintettel } \\
\text { arra, hogy az ér- } \\
\text { dekérvényesítés } \\
\text { eszköztárában } \\
\text { kizárólag a veze- } \\
\text { tői kommuniká- } \\
\text { ció érvényesül, } \\
\text { a csoport véle- } \\
\text { ménye elsikkad. }\end{array}$ \\
\hline $\begin{array}{l}\text { Demokra- } \\
\text { tikus }\end{array}$ & $\begin{array}{l}\text { A kommuniká- } \\
\text { ció kezdemé- } \\
\text { nyezője a cso- } \\
\text { port összes } \\
\text { tagja lehet, } \\
\text { függetlenül an- } \\
\text { nak hierarchi- } \\
\text { ában betöltött } \\
\text { szerepkörétől. }\end{array}$ & $\begin{array}{l}\text { A csoport összes } \\
\text { tagjának érdekérvé- } \\
\text { nyesítésére - a kom- } \\
\text { munikáció folyamatá- } \\
\text { ban - lehetőség van. } \\
\text { A vezető figyelembe } \\
\text { veszi a csoport tagjai- } \\
\text { nak érdekeit. }\end{array}$ & $\begin{array}{l}\text { A kommuni- } \\
\text { káció a veze- } \\
\text { tőtől a cso- } \\
\text { port tagjai } \\
\text { felé, és inverz } \\
\text { irányban is } \\
\text { megvalósul. }\end{array}$ & $\begin{array}{l}\text { A csoport } \\
\text { tagjainak } \\
\text { lehetőségük } \\
\text { van arra, } \\
\text { hogy az el- } \\
\text { hangzottakra } \\
\text { reflektáljanak } \\
\text { és véleményt } \\
\text { nyilvánítsa- } \\
\text { nak. }\end{array}$ & $\begin{array}{l}\text { A kommunikáció } \\
\text { hatékony, mert } \\
\text { a csoportkohézió } \\
\text { eszköztárával } \\
\text { segíti a munka- } \\
\text { végzést, ahol } \\
\text { minden egyes } \\
\text { résztvevő véle- } \\
\text { ményének a dön- } \\
\text { tés formájában } \\
\text { jelentősége van. }\end{array}$ \\
\hline $\begin{array}{l}\text { Laissez- } \\
\text { faire }\end{array}$ & $\begin{array}{l}\text { Kommuniká- } \\
\text { ciót a csoport } \\
\text { tagjai, és a ve- } \\
\text { zető is kezde- } \\
\text { ményezhet, de } \\
\text { általában a ve- } \\
\text { zetőtől indul. }\end{array}$ & $\begin{array}{l}\text { A csoport tagjainak } \\
\text { érdekeit a vezető fi- } \\
\text { gyelembe veszi, mert } \\
\text { a feladatvégrehajtás } \\
\text { során módszert nem } \\
\text { határozzák meg. Sza- } \\
\text { badelvúségre alapoz. }\end{array}$ & $\begin{array}{l}\text { A kommuni- } \\
\text { káció iránya } \\
\text { a csoport } \\
\text { tagjaitól, a ve- } \\
\text { zető kezde- } \\
\text { ményezésére } \\
\text { ugyanúgy } \\
\text { irányulhat. }\end{array}$ & $\begin{array}{l}\text { A csoport } \\
\text { összes tagja } \\
\text { felhatalma- } \\
\text { zást kap, } \\
\text { hogy az el- } \\
\text { hangzottakra } \\
\text { reagáljon } \\
\text { és reflektál- } \\
\text { jon, de a ve- } \\
\text { zető részéről } \\
\text { a közömbös- } \\
\text { ség tetten } \\
\text { érhető. }\end{array}$ & $\begin{array}{l}\text { Hatékonysága } \\
\text { közepes, mert } \\
\text { bár keretet szab, } \\
\text { és a végrehajtó } \\
\text { kreativitását } \\
\text { erősíti, mégsem } \\
\text { konszenzusra, } \\
\text { hanem közöm- } \\
\text { bösségre, és ma- } \\
\text { gától müködő/ } \\
\text { müködtethető } \\
\text { folyamatokra, } \\
\text { és csoportkohé- } \\
\text { zióra összpon- } \\
\text { tosít. }\end{array}$ \\
\hline
\end{tabular}

A kiscsoportos kommunikáció során az autoriter vezetési stílus esetében a kommunikáció kezdeményezője szintén csak a vezető lehet, a végrehajtó nem kap lehetőséget, hogy megindítsa az interakciót. A vezető kizárólag a saját érdekeinek megvalósulására koncentrál, a csoport érdekeinek képviselete nem valósul meg. A kommunikáció egyoldalú, ami a vezető prioritását és felsőbbrendűségét hirdeti. A végrehajtó nem reflektálhat az elmondottakra, tekintettel arra, hogy a kommunikáció egyoldalúsága 
miatt szóhoz sem juthat. Hatékonyság tekintetében gyenge, tekintettel arra, hogy az érdekérvényesítés eszköztárában kizárólag a vezetői kommunikáció érvényesül, a csoport véleménye elsikkad.

A demokratikus vezető esetén a kommunikáció kezdeményezője bárki lehet függetlenül attól, hogy a csoport hierarchiájában mely területen lát el feladatokat. A kommunikáció lehetőséget biztosít a csoport tagjai részére, hogy annak teljes folyamatában az érdekeiket érvényesíthessék, amelyet a vezető részükre biztosít, azok figyelembevételével. A kommunikáció a vezetőtől a csoport tagjai felé, és inverz irányba is megvalósul. Szerves része a reflektálás, és a véleménynyilvánítás, a kritikai szemlélet. A kommunikáció hatékony, mert a csoportkohézió eszköztárával segíti a munkavégzést, ahol minden egyes résztvevő véleményének a döntés formájában jelentősége van.

A ráhagyó stílus vonatkozásában megfigyelhető, hogy a kommunkáció kétoldalú, az a vezetőtől és a végrehajtótól is egyaránt indulhat, bár jellemzően azt a vezető kezdeményezi. A feladatvégrehajtás során a módszert nem jelölik ki, nagy szerephez jut a szabadelvűség. Mint ahogy az a ráhagyó modell minden ágazatában is a kommunikáció gyakorlásában is megnyilvánul, hogy a vezető a folyamatba csak akkor avatkozik be, ha szükséges, addig a közömbösség és a közöny érhető tetten. Hatékonysága közepes, mert bár keretet szab, és a végrehajtó kreativitását erősíti, mégsem konszenzusra, hanem közömbösségre, és magától működő/müködtethető folyamatokra, és csoportkohézióra összpontosít.

\section{Összefoglalás}

Ha a kétkülönböző környezeti kommunikációt elemezzük, és azt az etikai kódexben foglalt, illetve a vezetőkkel szemben támasztott követelményrendszerrel összevetjük, megállapíthatjuk, hogy az autokratikus vezetési stílus teljes mértékben ellentétes azon etikai elvárásokkal, amelyeket a kódex ajánl. Milyen az az autokrata vezető, és milyen mértékben bajtársias kollégáival szemben, aki munkatársaival együttmúködésre nem törekszik, velük kulturálatlanul viselkedik, és nem a kölcsönös tisztelet, megbecsülés szellemében érintkezik? Önmagában, hogy a végrehajtói állományt az érdekérvényesítésben, és a véleménynyilvánításban korlátoz, már ezen alapelvvel szembehelyezkedik, így hatékonysága gyenge lesz. (Nem felejthetjük el, hogy a 20. század hajnalán az emberi szabadságjogok kiemelt jelentőséghez jutottak.) ${ }^{36}$ A kommunikáció során önző magatartást tanúsít, támogatást nem nyújt, mert a visszacsatolási rendszert megszünteti, ami újabb problémák generálását teszi lehetővé, ami hátráltatja a problémamegoldó rendszer működtetését. A véleménynyilvánítás és érdekérvényesítés tekintetében az autoriter vezetô részrehajló, munkatársai véleményét nem hallgatja meg, félbeszakítja őket, tanácsaival a munkavégzést nem segíti elő. A kétirányú kommunikáció a feltétele a szervezet hatékony múködésének, ezért minden vezetőnek olyan helyzetet

36 Kovács István (2018a) 7-29. 
kell teremtenie, amely erre lehetőséget nyújt. ${ }^{37}$ Ezt az autoriter vezető nem teszi meg. Hatékonysága gyenge, amely így korrelál a munkavégzéssel összekapcsolt teljesítménynyel, hisz ez a munkafolyamatokban is megmutatkozik.

Ha a két különböző környezeti kommunikációt elemezzük, és azt az etikai kódexben foglalt, a vezetőkkel szemben támasztott követelményrendszerrel összevetjük, megállapíthatjuk, hogy a demokratikus vezetési stílus teljes mértékben megfelel azon etikai elvárásoknak, amelyeket a kódex ajánl. A demokratikus vezető bajtársias kollégáival szemben, munkatársaival együttmüködésre törekszik, velük kulturáltan viselkedik, együttmúködésüket kölcsönös tisztelet és megbecsülés övezi. A végrehajtói állományt az érdekérvényesítésben és a véleménynyilvánításban nem korlátozza, inkább támogatja, meghallgatja, így hatékonysága erős lesz. A kommunikáció során önzetlen magatartást tanúsít, támogatást nyújt, mert a visszacsatolási rendszerben mindenki számára reflektálási és reagálási jogosultságot teremt. Ez segíti a problémamegoldó rendszer múködtetését. A véleménynyilvánítás és érdekérvényesítés tekintetében a demokratikus vezető elfogulatlan, munkatársai véleményét mindig meghallgatja, tanácsaival és iránymutatásával a munkavégzést elősegíti. Hatékonysága erős, amely így korrelál a munkavégzéssel összekapcsolt teljesítménnyel, a csoportkohézió erősödésével.

A laissez-faire vezetési stílus részben felel csak meg azon etikai elvárásoknak, amelyeket a kódex ajánl. A laissez-faire vezető bajtársias kollégáival szemben, munkatársaival együttmúködésre törekszik, velük kulturáltan viselkedik, együttmúködésüket kölcsönös tisztelet és megbecsülés övezi, azonban ez túlzottan nagy szabadságelvűségre és önállóságra építkezik. A végrehajtói állományt az érdekérvényesítésben és a véleménynyilvánításban nem korlátozza, meghallgatja álláspontjukat, de túlzottan abba sem avatkozik bele, a visszacsatolási rendszer önmagában részbeni egyoldalúságot mutat. A kommunikáció során önzetlen magatartást tanúsít, mindenki számára reflektálási és reagálási jogosultságot teremt. Ez segíti a problémamegoldó rendszer múködtetését, de a tagok önállóan vesznek benne részt. A véleménynyilvánítás és érdekérvényesítés tekintetében a laissez-faire vezető elfogulatlan, munkatársai véleményét mindig meghallgatja, de nincs tanács, iránymutatás, csak egy keret, amin túl a végrehajtók nem terjeszkedhetnek, azt pedig ők töltik ki tartalommal. Hatékonysága közepes, amely így részben korrelál a munkavégzéssel összekapcsolt teljesítménnyel, a csoportkohézió erősödésével.

Az elemzőmunka rávilágított arra, hogy vezetési stílustól függően alakul a kommunikáció, az üzenet (parancs, feladat, utasítás) a befogadóra hatást gyakorol, a kiváltott hatás pedig a vezetési stílus jellemzőivel korrelál. Hipotézisemet így sikerült alátámasztanom. Minél inkább szoros és korlátozott a vezetési stílus kommunikációja, annál inkább képes arra, hogy a teljesítményt negatív irányba befolyásolja. Milyen végrehajtói állomány dolgozna szívvel, lélekkel egy adott szakterületen, ha a munkáltatója, alapjogaiban korlátozza, valamint a véleménynyilvánítás és érdekérvényesítés eszköztárában gyakorolt jogosultságainak gyakorlását korlátozza? A közbiztonság mint alapvető tár-

37 Czuprák-Kovács (2017) 
sadalmi cél kielégítése nem múködhet csoportkohézió nélkül. Szoros együttmúködésre van szükség, amely hiába épül alá-fölé rendeltségen alapuló hierarchizált viszonyokra, ha abból az etikus magatartás, leginkább a vezetők részéről a végrehajtói állomány irányába hiányzik. A vezetési stílusok ötvözésének olyan mezsgyéjén célszerű haladni, amely bizonyos tekintetben ugyan erősen szabályoz, de mindezt úgy teszi, hogy a jogok érvényesítése, így különös tekintettel a jogok gyakorlására és a kötelmek teljesítésére részrehajlás nélkül, elfogulatlanul kiemelt hangsúlyt fektet. Együttműködés, támogatás és manuális irányítás, a kommunikáció olyan eszköztárának felhasználásával, ami a parancsnoki szerepkört ugyan tiszteletben tartja, de az etikus magatartás gyakorlását példaként állítja a vezetői és végrehajtói állomány elé. Az etikus és parancsuralmi rendszerben alkalmazott kommunikációt az alábbi innovációs, és fejleszthető tudásbázissal szeretném segíteni.

Egy vezetőnek a kétpólusú kommunikációra mindig nyitottnak kell lennie, a kompetencia fejlesztésében a kezdeményezésnek fontos szerepe van. Ezért van kiemelt jelentősége annak, hogy a vezető a kommunikációja során (is) megfelelő vezetési stílust válasszon, így vívhatja csak ki a végrehajtói, alárendelti állomány tiszteletét. A kommunikáció sikerességét, nemcsak a vezetési stílusok tulajdonságai, hanem különböző tényezők, mint például a motiváció, résztvevők attitűdjei és az érzékelt kompetenciák összessége is befolyásolja.

\section{IRODALOMJEGYZÉK}

Czuprák Ottó - Kovács Gábor (2017): A szervezetvezetés elmélete. Budapest, Dialóg Campus Kiadó.

Deák József (2014): A Belügyi Szemle Tájékoztatójában a médiával kapcsolatban megjelent anyagok (1963-1972). Magyar Rendészet, 14. évf. 2. sz. 127-137.

Deák József (2016): A Belügyi Szemle létrehozását, múködését szabályozó parancsok, utasítások, 1962-1966. Hadtudományi Szemle, 9. évf. 4. sz. 20-34.

Eagly, Alice (2003): Transformational, Transactional, and Laissez-faire Leadership Styles: A Meta Analysis Comparing Woman, and Men. Psychological Bulletin, Vol. 129, No. 4. 569-591.

Fairholm, Matthew (2002): Defining Leadership: A review of Past, Present, and Future Ideas. USA, The George Washington University.

Fogarasi, Mihály - Kovács, István (2016): How to reveal the constructed worlds: the 2006's riots in Budapest. Internal Security, Vol. 8, No. 1.19-41.

Gordon, Thomas (1977): Leadership, Effectiveness, Training, Perigee. New York, The Berkling Publishing Group.

Hautzinger Zoltán (2010): A katonai büntetőjog rendszertana. Pécs, AndAnn Oktatási és Szolgáltató Kft.

Hersey, Paul - Blanchard, Kenneth H. - Johnson, Dewey E. (2000): Management of Organizational Behavior: Leading Human Resources. New Jersey, Prentice Hall.

Hodgins, Earl (2009): Leaders have a Duty to create Leaders. Ontario, Firefighting Canada Copyright.

Kouzes, James M. - Posner, Barry Z. (1995): The Leadership Challenge. Cleveland, Jossey-Bass Inc.

Kovács Gábor (2014): A rendészeti szervekben lejátszódó folyamatok. In Kovács Gábor szerk.: Rendészeti szervek vezetés, és szervezéselmélete. Budapest, Nemzeti Közszolgálati Egyetem.

Kovács Gábor (2016): A szervezeti, és vezetői kommunikáció sajátosságai a rendészeti szerveknél. Hadtudományi Szemle, 9. évf. 1. sz. 381-394. 
Kovács Gábor (2018a): A rendészeti szervezetekben lejátszódó vezetési folyamatok. Budapest, Dialóg Campus Kiadó.

Kovács Gábor (2018b): A hatékony vezetői teljesítmény fokozásának eszközei és módszerei a rendészeti szervezetekben. In Hautzinger Zoltán szerk.: A XXI. század biztonsági kihívásai. Pécsi Határör Tudományos Közlemények XX., Pécs. 135-146.

Kovács István (2014): Az emberkereskedelemhez szorosan kapcsolódó prostitúciós bűncselekmények - különösképpen a gyermekprostitúció - áldozatai emberi jogainak hazai vonatkozásai. Polgári Szemle, 10. évf. 3-6. sz. 419-430.

Kovács István (2015a): A rendőri korrupció és a prostitúció. Nemzetbiztonsági Szemle, 3. évf. 3. sz. 42-60.

Kovács István (2015b): Az üzletszerủ kéjelgéssel kapcsolatos rendőri visszaélések etikai vonatkozásai. Belügyi Szemle, 63. évf. 4. sz. 99-125.

Kovács István (2016a): A prostitúció jelensége és társadalmi kontrolljának vizsgálata empirikus módszerekkel. PhD-értekezés, Budapest, NKE.

Kovács István (2016b) A reglementációs prostitúció, és az emberi méltóság kapcsolata, különös tekintettel egy Alkotmánybírósági határozatra. Belügyi Szemle, 64. évf. 2. sz. 109-126.

Kovács István (2017a): Pornográfia, vagy prostitúció, esetleg mindkettő?. Hadtudományi Szemle, 10. évf. 4. sz. 449-484.

Kovács István (2017b): Vezetési funkciók egy helyi rendvédelmi szerv életében. Ellenőrzés, mint a kiadott szabályok, és utasítások betartásának (kontroll)feladata. Államtudományi Múhelytanulmányok, 21. sz. 1-30.

Kovács István (2018a): Prostitúció, és prohibíció a mai Magyarországon: avagy miért nem sikerül a rendőrségnek a szocializmust levetkőzni a XXI. században. Létünk, 2. sz. 7-29.

Kovács István (2018b): Vezetési funkciók egy helyi rendvédelmi szerv életében. Tervezés, mint az elérendő cél, és az ahhoz elvezető tevékenységek meghatározásának folyamata. Múszaki Katonai Közlöny, 28. évf. 3. sz. 194-212.

Lasswell, Harold (1948): The Structure and Function of Communication in Society. New York, The Communication of Ideas.

László Péter (2008): A poszttraumás stressz betegség pszichiátriai és szomatikus komorbiditása. Honvédorvos, 60. évf. 3-4. sz. 132-137.

Levin, Jonathan - Milgrom, Paul (2004): Introduction to Choice Theory. England, Oxford University Press.

Martel, Jacques (1998): Le grand dictionnaire des malaises et des maladies. Paris, Les Éditions ATMA Internationals Copyright.

Miller, Alice (2014): More already on the Central Comittee's Leading small Groups. China Leadership Monitor, No. 44. 1-8.

Northouse, Peter (2006): Leadership: Theory and Practice. Los Angeles, Sage Publications.

Ranschburg Jenő (2013): Erkölcs és jellem. Saxum Kiadó.

Ray, Sarbapriya - Ray, Ishita Aditya (2012): Understanding Democratic Leadership. Afro Asian Journal of Social Sciences, Vol. 3, No. 3. 1-26.

Stephen, Covey (1991): Principle Centered Leadership. New York, Simon and Schuster.

Szabó Csaba (2014): A katolikus lelkipásztori szolgálat rendőrségi aspektusának kutatása II. Hadtudományi Szemle, 7. évf. 2. sz. 159-164.

Szabó Csaba (2016): A katolikus rendőrségi lelkipásztori modell válaszai a rendőrök erkölcsi és pszichikai problémáira. In Szabó Csaba szerk.: Studia Doctorandorum Alumnae. Budapest, Doktoranduszok Országos Szövetsége. 405-406.

Valcsicsák Imre (2013): Rendészeti (szakmai) etika. Budapest, Nemzeti Közszolgálati Egyetem. 


\section{Jogforrás}

1994. évi XXXIV. törvény a rendőrségról. Forrás: https://net.jogtar.hu/jogszabaly?docid=99400034.TV (2018. 09. 17.)

\section{ABSTRACT \\ Leadership Status and Communication in the Command System, with Particular Reference to the Code of Ethics for the Police, as well as Leadership Styles Based on the Lasswell Model}

KOVÁCS István

Personal relationships are defined by the relative power and status of each participant. This is especially true in communication. According to the Code of Ethics of the Police Service, colleagues are encouraged by leaders' personal exemplary, they listen to their opinions, giving advice and guiding them to work. The basic communication model developed by Lasswell examines who is communicating to whom and what they say, what channel they communicate and which is the effect of the communication. The study examines how the communication of the autocratic, democratic and laissez-faire leadership style is realised in practice, whether the ethical principles prevail.

Keywords: leadership styles, leadership theory, communication, police ethics, Lasswell model 